Original Research Paper

\title{
Aplikasi Kahoot Sebagai Alat Pengujian Terhadap Pencapaian Murid dalam Mata Pelajaran Sejarah
}

\author{
Laili Farhana Md Ibharim ${ }^{1}$, Athirah Hanis Ariffin ${ }^{1}$ \\ ${ }^{1}$ Universiti Pendidikan Sultan Idris.
}

\author{
Article History \\ Received: \\ 07.09.2019 \\ Revised: \\ 12.10.2019 \\ Accepted: \\ 25.11.2019 \\ *Corresponding Author: \\ Laili Farhana Md Ibharim \\ Email: \\ laili@fskik.upsi.edu.my
}

\begin{abstract}
Abstrak: Kajian ini bertujuan untuk mengenal pasti kesan penggunaan aplikasi Kahoot dalam mengukur pencapaian murid bagi mata pelajaran Sejarah Tingkatan 1. Objektif kajian ini adalah membangunkan alat pengujian pencapaian menggunakan aplikasi Kahoot untuk mata pelajaran Sejarah; dan mengenal pasti perbezaan penggunaan aplikasi Kahoot dan ujian bertulis dalam mengukur pencapaian murid. Reka bentuk kajian ini adalah berbentuk kuantitatif terhadap 30 orang peserta yang terdiri daripada murid Tingkatan 1 di sebuah sekolah di Melaka. Kajian mengapliksikan kaedah tinjauan dengan menggunakan soal selidik dan eksperimen menggunakan set ujian untuk melihat kesan pencapaian murid terhadap mata pelajaran Sejarah dengan menggunakan dua alat pengujian yang berbeza. Hasil kajian mendapati alat pengujian menggunakan aplikasi Kahoot memberikan hasil dapatan yang positif oleh murid dan pencapaian bagi murid yang menggunakan aplikasi Kahoot adalah lebih tinggi berbanding menggunakan alat pengujian konvensional.
\end{abstract}

Kata Kunci: Alat Ujian, Aplikasi Kahoot, Pencapaian, Sejarah.

Application of Kahoot as a Testing Tool to Student Achievement in History Subjects

Abstract: This study aimed to identify the impact of using the Kahoot application in measuring student achievement for Level 1 history subjects. The objectives of this study were to develop achievement testing tools using the Kahoot application for History subjects; and identify differences in use of the Kahoot application and written tests in measuring student achievement. The design of this study was quantitatively based on 30 participants from Form 1 students at a school in Malacca. The study applied survey methods using questionnaires and experiments using test sets to see the impact of student achievement on History subjects using two different testing tools. The results showed that testing tools using the Kahoot app gave students positive results and the achievement for students using the Kahoot app was higher than using conventional testing tools.

Keywords: Testing Tools, Kahoot Applications, Achievements, History. 


\section{Pendahuluan}

Kepesatan Teknologi Maklumat dan Komunikasi pada abad ke-21 ini menjadikan sistem pendidikan di Malaysia bersifat dinamik dengan wujudnya pelbagai alatan, pendekatan dan kaedah yang digunapakai dalam proses pengajaran dan pembelajaran. Selari dengan pendidikan abad ke-21, murid yang terdiri daripada generasi digital ini lebih tertarik kepada keseronokan belajar menggunakan aplikasi komputer [1]. Hal ini disokong oleh Bennett, Agostinho dan Lockyer [2] yang turut menyatakan bahawa pembelajaran yang berkesan ialah pembelajaran yang menyeronokkan di mana implikasi dari keseronokan belajar adalah apabila pelajar lebih berminat dan tertarik untuk terus belajar.

Pelbagai bahan pembelajaran digital yang telah disediakan oleh Bahagian Teknologi Pendidikan bagi membantu guru dalam pengajaran mereka antaranya koswer pembelajaran, VLE Frog dan EduwebTV. Namun bagaimana dengan bahan untuk menguji pencapaian pembelajaran murid? Hal ini penting bagi menentukan objektif pengajaran dan pembelajaran dapat dicapai atau tidak. Alat pengujian konvensional yang menggunakan pen dan kertas telah lama dipraktikan untuk menguji kefahaman dan mengukur pencapaian murid terhadap sesuatu mata pelajaran. Menurut Ramlah, Shahabuddin dan Mahani [3], penggunaan alat pengujian konvensional kurang membantu murid berfikir secara kritikal dan murid terlalu pasif ketika menjawab soalan. Tambahan pula, murid akan menggunakan masa yang lama untuk membaca soalan yang terlalu panjang sehingga masa untuk menjawab semua soalan menjadi singkat terutamanya yang memerlukan murid memahami peristiwa dan mengingati fakta seperti dalam mata pelajaran Sejarah. Disebabkan oleh itu, murid tidak dapat memberi fokus dan tumpuan terhadap soalan dan akan gagal menjawab soalan dengan betul [4].

Kajian yang dijalankan oleh Deterding [5] menyatakan bahawa antara pendekatan yang sesuai digunakan oleh guru sebagai alat pengujian pada abad ini ialah pembelajaran berasaskan permainan. Aplikasi Kahoot yang mempunyai ciri-ciri permainan seperti skor, ganjaran dan interaksi mewujudkan sebuah pembelajaran yang aktif dan lebih menyeronokkan. Penggunaan kombinasi elemen-elemen multimedia yang terdapat pada aplikasi Kahoot ini membolehkan pembelajaran berasaskan teori kognitif dapat dilaksanakan dan diperkembangkan penggunaanya dalam pengajaran dan pembelajaran dalam mata pelajaran Sejarah. Hal ini kerana, dalam aplikasi Kahoot, terdapat dua jenis kuiz yang boleh dipilih oleh murid, iaitu mod Classic (persaingan antara individu) dan mod Team (persaingan antara pasukan). Setiap jawapan yang dijawab dengan betul akan diberikan markah dan diakhir permainan, markah dan permain terbaik akan dipaparkan. Justeru itu, kajian ini dijalankan adalah untuk mengkaji kesan penggunaan aplikasi Kahoot sebagai salah satu alat pengujian pencapaian murid dalam mata pelajaran Sejarah.

Bagi mencapai tujuan kajian, objektif kajian ini adalah i) membangunkan alat pengujian pencapaian menggunakan aplikasi Kahoot untuk mata pelajaran Sejarah; dan ii) mengenal pasti perbezaan kesan penggunaan aplikasi Kahoot dan ujian bertulis dalam mengukur pencapaian murid. Penggunaan aplikasi Kahoot ini adalah usaha untuk menentukan penguasaan mata pelajaran Sejarah dan dalam masa yang sama juga dapat meningkatkan semangat patriotisme murid.

\section{Pembangunan Aplikasi Kahoot Sebagai Alat Pengujian Pencapaian Pelajar Dalam Mata Pelajaran Sejarah}

Alat pengujian menggunakan aplikasi Kahoot ini menggunakan model ADDIE sebagai tunjang utama dalam proses pembangunan. Model ADDIE mempunyai lima fasa utama iaitu analisis (Analysis), reka bentuk (Design), pembangunan (Develop), pelaksanaan (Impelementation) dan penilaian (Evaluation). ADDIE merupakan sebuah model reka bentuk instruksi yang sering digunapakai dalam pembangunan aplikasi pendidikan [6]. Tujuan model reka bentuk ini digunakan ialah untuk memastikan perancangan pembangunan yang dirancang dapat dijalankan dengan berkesan dan aplikasi yang dibangunkan berkualiti serta menepati ciri-ciri yang diperlukan.

\subsection{Fasa Analisis}

Bagi membangunkan aplikasi Kahoot sebagai alat pengujian pencapaian murid bagi mata pelajaran Sejarah, langkah pertama yang pengkaji harus lakukan ialah perlu mengenal pasti keperluan pembelajaran murid serta kaedah yang bersesuaian bagi membantu mengatasi masalah yang mereka hadapi. Menurut Hung dan Wong [7], analisis tahap kebolehan, kaedah belajar dan sikap murid adalah perkara utama dan penting yang perlu dianalisis sebelum aplikasi pembelajaran dibangunkan. Analisis 
keperluan dilakukan melalui kajian perpustakaan dan temubual bersama guru yang mengajar mata pelajaran Sejarah untuk mendapatkan makluman keperluan seperti Jadual 1.

Jadual 1. Analisis Keperluan Aplikasi Kahoot Sebagai Alat Pengujian

\begin{tabular}{|c|c|}
\hline KEPERLUAN & PENERANGAN \\
\hline Kandungan & $\begin{array}{l}\text { Topik yang dipilih adalah Zaman Prasejarah yang terdapat pada Bab } 3 \\
\text { dalam buku teks Sejarah Tingkatan 1. Topik ini memerlukan murid } \\
\text { memahami peristiwa dan mengingati fakta seperti tempoh masa, } \\
\text { lokasi, ciri-ciri kehidupan, dan bukti penemuan dimana tahap kognitif } \\
\text { berada pada tahap pengetahuan dan tahap kefahaman berdasarkan } \\
\text { Teksonomi Bloom [13]. Soalan yang dibina juga adalah mengikut } \\
\text { kemampuan pelajar yang telah ditentukan berpandukan Jadual } \\
\text { Spesifikasi Ujian yang telah disemak oleh } \\
\text { guru panatia Sejarah }\end{array}$ \\
\hline $\begin{array}{c}\text { Kaedah } \\
\text { pembelajaran }\end{array}$ & $\begin{array}{l}\text { Pembelajaran berasaskan permainan dijadikan asas kaedah } \\
\text { pembelajaran kerana aplikasi Kahoot mempunyai ciri-ciri permainan } \\
\text { seperti cabaran, peraturan, matlamat dan maklum balas [12]. Cabaran } \\
\text { diberikan dalam bentuk soalan. Setiap soalan akan ditentukan jumlah } \\
\text { skor berdasarkan aras soalan dan ditetapkan tempoh masa untuk } \\
\text { menjawab. Murid yang memperolehi jumlah skor tertinggi adalah } \\
\text { pemenang. }\end{array}$ \\
\hline Sikap murid & $\begin{array}{l}\text { Sikap murid terhadap aplikasi Kahoot terutamanya dari aspek minat, } \\
\text { motiivasi dan penerimaan diperhatikan bagi mengenalpasti kesan } \\
\text { terhadap pencapaian pelajar. }\end{array}$ \\
\hline $\begin{array}{l}\text { Keperluan } \\
\text { perkakasan dan } \\
\text { perisian }\end{array}$ & $\begin{array}{l}\text { Perkakasan yang diperlukan adalah komputer riba atau komputer } \\
\text { peribadi yang dilengkapi internet manakala perisian yang diperlukan } \\
\text { adalah Adobe Photoshop untuk suntingan gambar dan Filmora untuk } \\
\text { suntingan video dan audio. }\end{array}$ \\
\hline
\end{tabular}

\subsection{Fasa Reka bentuk}

Reka bentuk alat pengujian menggunakan aplikasi Kahoot perlulah mengikut keperluan yang diperlukan seperti yang telah dianalisis di dalan fasa analisis. Proses merekabentuk perlulah menggambil kira keperluan daripada guru dan murid sebagai pengguna yang akan menggunakan aplikasi yang dibangunkan. Dari segi reka bentuk kandungan, 30 soalan pengukuhan yang menggunakan Dokumen Standard Kandungan Pentaksiran (DSKP) sebagai panduan bagi mencapai objektif pembelajaran. Soalan yang dibina juga mengikut spesifikasi item yang ditetapkan dan merupakan soalan yang digunakan semasa ujian melalui kaedah konvensional dijalankan.

Reka bentuk interaksi penting untuk melihat bagaimana aplikasi yang dibangunkan berfungsi secara keseluruhan [8]. Bagi kajian ini, papan cerita dan carta alir disediakan sebelum proses pembangunan untuk memastikan aplikasi Kahoot yang dibangunkan beroperasi dengan baik dan mesra pengguna. Setiap elemen yang digunakan dalam pembangunan aplikasi ini akan ditunjukkan. Antaranya ialah teks dan imej yang digunakan, fungsi setiap ikon dan bagaimana aliran aplikasi ini bertindak. Seterusnya, reka bentuk persembahan juga diambil kira. Reka bentuk persembahan yang baik dan seimbang digunakan untuk meningkatkan minat dan pengetahuan murid apabila menggunakan aplikasi pendidikan yang dibangunkan. Elemen multimedia seperti teks, warna, grafik, 
audio, video dan animasi adalah perkara yang difokuskan ketika menentukan reka bentuk persembahan agar memenuhi keperluan pengguna semasa menggunakannya.

\subsection{Fasa Pembangunan}

Fasa pembangunan ialah fasa yang melibatkan penetapan arahan-arahan yang telah direka pada fasa reka bentuk. Perancangan yang telah dilakukan pada fasa reka bentuk akan diterjemahkan dalam proses pembangunan. Pengkaji menggunakan laman web Kahoot (https://create.kahoot.it/) untuk proses pembangunan. Proses pembangunan bermula dengan mendaftar akaun dan memlilih kuiz sebagai bentuk aplikasi kerana tujuan aplikasi ini adalah sebagai alat mengukur pencapaian murid. Semasa proses menetapkan soalan, empat pilihan jawapan seperti kaedah konvensional, yang diwakili dalam bentuk segi tiga, bulat, pentagon dan segi empat untuk setiap soalan. 20 saat ditetapkan untuk setiap soalan kerana aras soalan adalah pada tahap pengetahuan dan kefahaman sahaja.

\subsection{Fasa Pelaksanaan}

Guru telah melaksanakan sesi pengujian pencapaian terhadap topik Zaman Pra Sejarah menggunakan aplikasi Kahoot terhadap 30 orang murid yang terdiri daripada pelajar Tingkatan 1 di makmal komputer sekolah. Setelah sesi pengajaran selesai, murid diberi tempoh satu jam untuk menjawab soalan secara kaedah konvensional menggunakan pen dan kertas. Kertas jawapan dikumpulkan dan tempoh masa yang sama juga diberikan bagi menjawab soalan menggunakan aplikasi Kahoot. Guru akan memeriksa jawapan bagi menentukan skor pada kertas manakala skor akan diperolehi secara automatik pada aplikasi Kahoot. Perbezaan skor antara dua alat pengujian ini akan dinilai bagi menetukan kesan terhadap pencapaian murid.

\subsection{Fasa Penilaian}

Penilaian formatif lebih berbentuk kepada kesahan kandungan yang disahkan oleh guru panatia Sejarah bagi memastikan soalan yang dibina adalah sesuai untuk tahap pelajar. Selain itu penilaian terhadap antaramuka dan navigasi setiap bahagian dalam aplikasi juga dititikberatkan supaya aplikasi dapat berfungsi dengan baik. Bagi penilaian sumatif, murid diberikan soal selidik setelah mereka menggunakan aplikasi Kahoot ini. Soal selidik ini bertujuan untuk menilai aplikasi secara menyeluruh merangkumi aspek kebolehgunaan iaitu kecekapan, keberkesanan dan kepuasan pengguna terhadap aplikasi Kahoot sebagai alat penguji pencapaian murid untuk mata pelajaran Sejarah.

\section{Kesan Penggunaan Aplikasi Kahoot Sebagai Alat Pengujian Pencapaian Murid Dalam Mata Pelajaran Sejarah}

Data dikumpulkan semasa sesi pelaksanaan dan penilaian seperti yang dinyatakan dalam proses pembangunan. Data kemudiannya dianalisis menggunakan analisis deskriptif dengan melihat nilai min responden dan analisis statistik melalui ujian-T untuk melihat perbezaan antara alat pengujian konvensional dan aplikasi Kahoot sebagai alat pengujian.

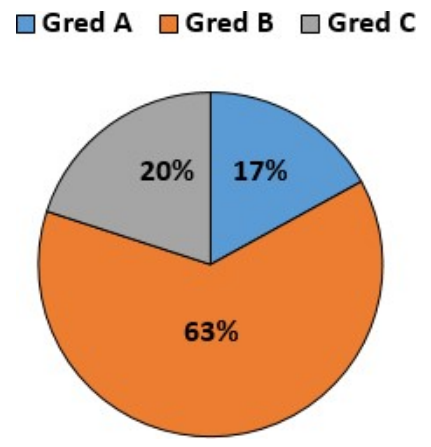

Rajah 1. Pencapaian Murid Apabila Menggunakan Alat Pengujian Konvensional 
Melalui ujian kebolehgunaan dalam soal selidik terhadap aplikasi Kahoot, nilai skor min bagi aspek kecekapan adalah 4.71, nilai skor min bagi aspek keberkesanan adalah 4.80 dan nilai skor min bagi aspek kepuasan pengguna adalah 4.55. Menurut Uma [9], nilai skor min yang berada pada nilai 3.50 hingga 5.0 adalah berada pada tahap yang tinggi. Hal ini menunjukkan bahawa aplikasi Kahoot ini berada pada tahap kebolehgunaan yang tinggi dan sesuai untuk digunakan sebagai alat pengujian pencapaian bagi mata pelajaran Sejarah Tingkatan 1 .

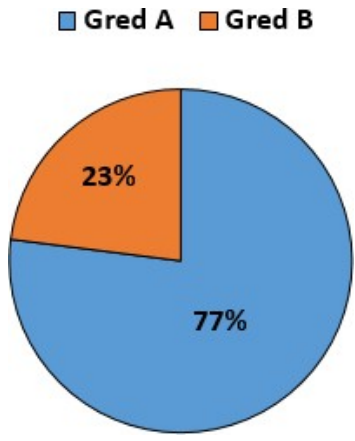

Rajah 2. Pencapaian Murid Apabila Menggunakan Aplikasi Kahoot

Perbandingan markah untuk dua alat pengujian ditunjukkan pada Rajah 1 dan Rajah 2 menunjukkan peratus peningkatan pencapaian murid yang memperolehi Gred A dalam mata pelajaran Sejarah meningkat daripada 17\% $(n=5)$ kepada $77 \%(n=23)$, Gred B menurun daripada $63 \%(n=19)$ kepada 23\% ( $\mathrm{n}=7)$ dan daripada 20\% $(\mathrm{n}=6)$ yang memperolehi Gred C kepada $0 \%(\mathrm{n}=0)$ apabila menggunakan aplikasi Kahoot.

Jadual 2. Min Skor Ujian Kaedah Konvensional dan Aplikasi Kahoot

\begin{tabular}{|l|r|r|r|r|}
\hline $\begin{array}{l}\text { Kaedah pengujian yang } \\
\text { digunakan }\end{array}$ & Mean & N & Std. Deviation & $\begin{array}{c}\text { Std. Error of } \\
\text { Mean }\end{array}$ \\
\hline konvensional & 72.00 & 30 & 7.125 & 1.301 \\
Kahoot & 88.47 & 30 & 5.244 & .957 \\
Total & 80.23 & 60 & 10.364 & 1.338 \\
\hline
\end{tabular}

Ujian-T digunakan untuk menentukan perbezaan kesan pencapaian murid antara alat pengujian konvensional dan aplikasi Kahoot terhadap mata pelajaran Sejarah. Berdasarkan Jadual 2, min untuk aplikasi Kahoot ialah 88.47 manakala kaedah konvensional ialah 72.00. Oleh yang demikian, nilai min untuk alat pengujian aplikasi Kahoot adalah lebih tinggi berbanding nilai min bagi konvensional. Bagi ujian ini, aras signifikan 2-tailed yang digunakan ialah .05.

Jadual 3. Min Skor Ujian Kaedah Konvensional dan Aplikasi Kahoot

\begin{tabular}{|c|c|c|c|c|c|c|}
\hline & \multicolumn{2}{|c|}{$\begin{array}{c}\text { Levene's Test for } \\
\text { Equality of Variances }\end{array}$} & \multicolumn{3}{|c|}{ t-test for Equality of Means } \\
\hline & & $\mathrm{F}$ & Sig. & $\mathrm{t}$ & df & $\begin{array}{l}\text { Sig. (2- } \\
\text { tailed) }\end{array}$ \\
\hline $\begin{array}{l}\text { marka } \\
\mathrm{h}\end{array}$ & $\begin{array}{l}\text { Equal variances } \\
\text { assumed } \\
\text { Equal variances not } \\
\text { assumed }\end{array}$ & 1.395 & .242 & $\begin{array}{l}-10.195 \\
-10.195\end{array}$ & $\begin{array}{r}58 \\
53.292\end{array}$ & $\begin{array}{l}.000 \\
.000\end{array}$ \\
\hline
\end{tabular}


Berdasarkan Jadual 3, perbezaan yang ditunjukkan dalam sampel aras signifikan .000, iaitu kurang dari .05. Oleh yang demikian, terdapat perbezaan yang jelas terhadap kesan pencapaian pelajar Justeru itu, alat pengujian aplikasi Kahoot merupakan alat yang lebih memberi kesan berbanding kaedah konvensional terhadap pencapaian murid dalam mata pelajaran Sejarah.

\section{Kesimpulan}

Selari dengan pendidikan abad ke-21 yang memberi fokus kepada integrasi teknologi dalam pendidikan, alat pengukuran pencapaian juga boleh didigitalkan melalui penggunaan aplikasi dan teknologi komputer. Selain daripada mempelbagaikan kaedah pengajaran, guru boleh mempelbagaikan kaedah pengujian. Namun begitu reka bentuk bagi sesuatu kaedah, alat atau pendekatan perlulah bersesuaian supaya objektif pembelajaran boleh dicapai. Reka bentuk pembangunan aplikasi Kahoot ini yang berpandukan model ADDIE secara sistematik telah menggabungkan elemen multimedia yang dapat memberi lebih kefahaman kepada murid. Kenyataan ini disokong oleh Jamalludin dan Zaidatun [8] yang menyatakan bahawa penggunaan elemen multimedia ini membantu murid dalam proses menerima, memproses maklumat dan mengkod semua maklumat dari storan memori dengan baik.

Ciri-ciri permainan yang disediakan pada aplikasi Kahoot memberi kesan terhadap motivasi serta minat murid. Murid tidak berasa sedang diuji dan tertekan seperti menggunakan kaedah pengujian konvensional. Malah mereka berasa sedang bermain sambil belajar. Murid juga bebas berinteraksi dan menjadikan proses pengajaran dan pembelajaran berada dalam keadaan yang aktif. Dapatan ini menyokong kajian yang dijalankan oleh Papastergiou [10], yang menyatakan bahawa aplikasi interaktif berjaya meningkatkan pencapaian murid dan motivasi mereka terhadap sesebuah mata pelajaran. Aplikasi Kahoot yang menerapkan penggunaan multimedia dan ciri permainan dalam reka bentuknya adalah sebuah alat pengujian yang efektif kerana penggunaan inovasi baharu dalam dunia pendidikan dapat membantu murid untuk meningkatkan kemahiran dan membina pengetahuan mereka sendiri terutamanya dalam mata pelajaran Sejarah yang memerlukan murid memahami peristiwa dan mengingati fakta dengan lebih berkesan.

Kesesuaian aplikasi Kahoot sebagai alat pengujian bagi mata pelajaran Sejarah mendorang murid untuk menjadi seorang pemikir yang kreatif mengaplikasikan pengetahuan yang telah diperolehi. Murid lebih teruja menjawab soalan secara digital kaedah konvensional yang hanya di atas kertas sahaja. Penggunaan aplikasi Kahoot menunjukkan murid akan lebih teruja dan bersemangat dengan kandungan pembelajaran dan pengajaran yang akan disampaikan oleh guru. Interaksi dan kognitif murid dalam mempelajari sesebuah pembelajaran juga turut meningkat. Kenyataan ini turut disokong oleh kajian yang dijalankan oleh Riding dan Rayner [11] yang menyatakan bahawa pembelajaran seseorang murid dipengaruhi oleh interaksi antara kognitif murid tersebut dan cara bahan pembelajaran itu disusun serta jenis isi kandungan yang digunakan.

Penggunaan aplikasi Kahoot sebagai alat pengujian ini adalah sangat bersesuaian lebih-lebih lagi penggunaannya dalam mata pelajaran Sejarah yang umum mengetahui mempunyai pelbagai fakta seperti peristiwa, tarikh, nama tokoh, nama tempat dan lain-lain lagi fakta yang perlu diingati. Oleh yang demikian, kesesuaian aplikasi Kahoot sebagai alat pengujian mampu meningkatkan prestasi murid menjadi lebih baik.

\section{Rujukan}

[1] C. Kivunja, "Theoretical Perspectives of How Digital Natives Learn," International Journal of Higher Education, vol. 3, no. 1, pp. 94, 2014.

[2] S. Bennett, S. Agostinho, and L. Lockyer, "Technology tools to support learning design: Implications derived from an investigation of university teachers' design practices," Computers \& Education, vol. 81, pp. 211-220, 2015.

[3] R. Jantan, S. Hashim, and M. Razali, Psikologi Pendidikan. Bentong: PTS Publications and Distributors, 2003.

[4] A. A. Wahap, "Konteks, Input, Proses dan Hasil Penggunaan Kaedah Ilustrasi Komik terhadap Pelajar Tingkatan Empat dalam Pengajaran dan Pembelajaran Mata Pelajaran Sejarah di salah sebuah Sekolah di Daerah Papar: Satu Kajian Kes," in Seminar Pendidikan Sejarah dan Geografi 2013, UMS, August 29-30, 2013, pp. 29-54. 
[5] S. Deterding, "Situated motivational affordances of game elements: A conceptual model," in Gamification: Using game design elements in non-gaming contexts, CHI, 2011.

[6] C. Peterson, "Bringing ADDIE to life: Instructional design at its best," Journal of Educational Multimedia and Hypermedia, vol. 12, no. 3, pp. 227-241, 2003.

[7] D. W. Hung, and A. F. Wong, "Activity theory as a framework for project work in learning environments," Educational Technology, vol. 40, no. 2, pp. 33-37, 2000.

[8] J. Harun, and Z. Tasir, Multimedia dalam pendidikan. Bentong: PTS Publication, 2003.

[9] Uma, S. Research Methods for Business: A Skill Building Approach, 4th ed. John Wiley \& Sons, Inc, 2003.

[10] M. Papastergiou, "Digital game-based learning in high school computer Science education: Impact on educational effectiveness and student motivation," Computers \& Education, vol. 52, no. 1, pp. 1-12, 2009.

[11] R. Riding, and S. R. Rayner, Cognitive style and learning strategies. London: Fulton, 1998.

[12] R. Dellos, "Kahoot! A digital game resource for learning," International Journal of Instructional Technology and Distance Learning, vol. 12, no. 4, pp. 49-52, 2000.

[13] B. S. Bloom, Taxonomy of Educational Objectives. Vol. 1: Cognitive Domain. New York: McKay, 1956. 